\title{
H.O. Lange-Prisen 2002 - Takketale
}

\author{
Aflektor, dr.phil. Hans Kirchhoff
}

\begin{abstract}
,I hvert fald er kravet til at historikerne blander sig ikke blevet mindre i det 21. ärhundrede end $i$ årtierne for. Det skyldes at vi står overfor en ny fjende når det gelder om at forstå krigsårene og de vilkär besattelsesgenerationen levede og virkede under. Den nye fjende hedder nymoralismen, der har fyldt tomrummet ud efter Koldkrigens ophor, og det der er kaldt ideologiernes sammenbrud. Med nymoralismen folger historielosheden, dvs. den manglende evne eller vilje til at anskue fortiden, og her besettelsen, ud fra dennes forudsatninger og egne pramisser.

Nymoralismen er intimt flettet sammen med offensiven for menneskerettigheder og internationalisering. Den er blevet en målestok for hvad der er relevant og irrelevant i besattelseshistorien, og hvad der er rigtigt og forkert. "Citat fra Hans Kirchhoff's' takketale ved uddelingen af H.O. Lange-Prisen den 17. september 2002.
\end{abstract}

$\mathrm{J}$ eg vil gerne rette en varm og hjertelig tak til Gads Fond og til Det Kongelige Bibliotek for tildeling af H.O. Langerisen 2002.

Det ville være en underdrivelse at sige at jeg er glad for at modtage hæderen og de mange rare penge der følger med, jeg er jublende glad - for ikke at bruge et stærkere udtryk. Og det hænger nok sammen med det forhold, at jeg ikke mindst efter Erland Kolding Nielsens smukke tale egentligt synes at prisen er ganske velfortjent!

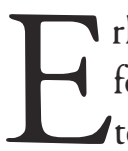
rland sagde nogle pæne ord om min forskning. Den vil jeg ikke kommentere her, for den vil jeg trygt overlade til bedømmelse af mine fagfæller i besættelseshistorien. Jeg er helt sikkert på at de vil rykke frem med det fulde kritiske og metodiske apparat når lejligheden byder sig til.

Men jeg vil gerne sige lidt om formidlingsaspektet - og specielt den side af det der vender udad imod offentligheden. Og her vil jeg knytte an til det Erland sagde om min generations rolle og andel heri. For det er jo ikke rigtigt - sådan som det ofte fremstilles i medierne når besættelsen og de store spørgsmål dukker op i den offentlige debat - at vi bare har siddet i vores elfenbenstårne og hygget os med ligegyldige emner, mens vi har overladt de vigtigste og farligste spørgsmål til journalisterne. Vi har faktisk alle taget vore tørn, i radio og TV og i de trykte medier, i foreningerne, $\mathrm{i}$ forsamlingshusene og på folkeuniversiteterne landet over.

Og det er jo heller ikke rigtigt at vi bare har siddet med vores "gulnede papirer" og skrevet for en snæver kreds af nikkende og rygklappende fagfæller - og gjort det i et sprog der er uforståeligt for menigmand! Faktisk har vi i min generation lagt mange kræfter i at udtrykke os på et mundret og klart dansk.

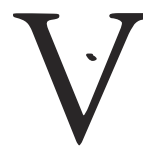
snakker meget på universiteterne $\mathrm{i}$ disse år om formidling. Det er nærmest blevet et modeord. Ved formidling forstår mange videoprogrammer, 
websider og museumsoplevelser - mens formidling via det skrevne eller talte ord ofte er en mærkværdig overset og nedvurderet form for kommunikation.

Når jeg fremhæver det her, er det fordi jeg ved denne festlige lejlighed gerne vil mindes min mentor Jørgen Hæstrup, sit historikerslægtleds store formidler, der satte et blivende stempel på alle os fra den anden generation af besættelsesforskere. Han krævede nemlig at historie skulle skrives for almindelige mennesker, så de ikke blot kunne forstå den, men også blive indfanget. Nogle af os skrev os senere væk fra Hæstrups nationale historiesyn på besættelsesårene. Men jeg tror ikke at nogen undgik at blive dybt påvirket af Hæstrups mantra: skriv dansk, din hund! Det gælder i hvert fald mig!

Hæstrup deltog selv i den offentlige debat. Han var ingen systemstormer. Men han var da medvirkende til at vælte hærchefen i 1961. Og der blev appelleret til hans faglige autoritet og til hans viden fra alle sider og kanter af det offentlige liv.

Ingen af os $i$ anden generation har haft hans pondus. Men man skulle da have været både lam og døv, hvis man ikke havde udnyttet den chance og det privilegium der lå i at ens forskningsområde var levende historie og nu i en menneskealder har været hot stuff i medierne!

Det har ikke altid været lige let. Som alle ved er der tale om en epoke i Danmarkshistorien, der spiller en betydelig rolle for vores nationale identitet, og hvortil der er knyttet meget stærke følelser og mange både personlige og politiske interesser.

Og så har vi jo oveni måttet bakse med tidens endnu levende aktører, der har været ubekvemme nok til at mene at de vidste bedre besked om hvad de selv havde gjort i "de fem forbandede år" end historikerne!

Det har været en tung og træls vej op ad bakke: Imod den store myte om at vi alle - også politikerne og myndighederne - havde været i modstandsbevægelsen fra den første besættelsesdag, om at vi alle havde været i samme båd, både rige og fattige og dem midt imellem, om det store sammenhold, og om skellet mellem helte og skurke og mellem ondt og godt.

Det har været en kamp imod uvidenhed og fordomme, men det har også været en kamp om holdninger, og en kamp der i den forstand ikke kan vindes, fordi der altid vil være flere sandheder om besættelsen - også blandt historikerne.

Men det er et oprydningsarbejde og en rekonstruktion som jeg håber ikke har været forgæves. Eller har den spørger jeg ofte mig selv i mere grå stunder end dem jeg befinder mig i i dag.

$\mathrm{I}$ hvert fald er kravet til at historikerne blander sig ikke blevet mindre i det 21 . århundred end i årtierne før.

Det skyldes at vi står overfor en ny fjende når det gælder om at forstå krigsårene og de vilkår besættelsesgenerationen levede og virkede under. Den nye fjende hedder nymoralismen, der har fyldt tomrummet ud efter Koldkrigens ophør, og det der er kaldt ideologiernes sammenbrud.

Med nymoralismen følger historieløsheden, dvs. den manglende evne eller vilje til at anskue fortiden, og her besættelsen, ud fra dennes forudsætninger og egne præmisser. Nymoralismen er intimt flettet sammen med offensiven for menneskerettigheder og internationalisering. Den er blevet en målestok for hvad der er 


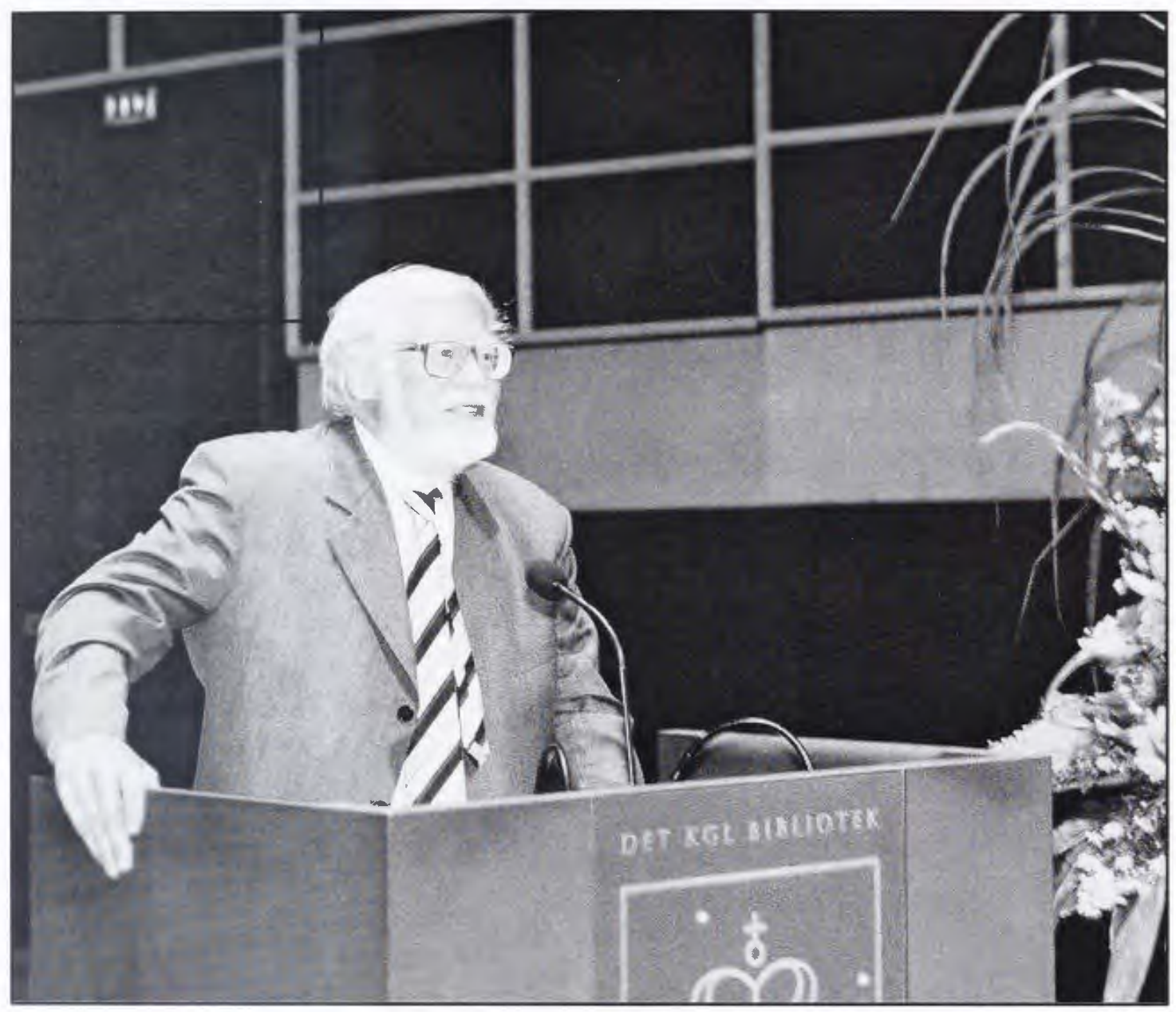

Hans Kirchhoff takker for tildelingen af irets H.O. Lange-Pris, som i är er gaiet til forskeren og formidleren Hans Kirchhoff for hans seneste werk Samarbejde og modstand under besæutelsen. En politisk historie. (Foto: Det Kongelige Bibliotek).

relevant og irrelevant i besættelseshistorien, og hvad der er rigtigt og forkert

Nu er denne nymoralistiske trend ikke kun et dansk fæenomen. Den huserer overalt i Europa som et opgor med den generation der gennemlevede og gennemled den II verdenskrig. Svenskerne tumler med deres protyske neutralitetspolitik, deres eksport af jernmalm og kuglelejer til Nazityskland, og passiviteten under Holocaust. Norge - som vi ellers kender som landet med de rene linjer og "de norske tilstande"-slås med arven fra Quisling og har også haft problemer med de beslaglagte jodiske formuer, der forst efter det storste pres er blevet betalt tilbage i de allerseneste år. Schweiz bakser med det jodiske guld, eksporten til den tyske krigsmaskine, og den ubamhjertige flygtningepolitik for og under krigen. Frankrig kæmper med arven fra Vichy. Hver eneste retssag imod gamle kollaboratorer åbner for en byge af mudderkastning mellem samarbejds- og modstandsssynspunktet, der river alle de gamle sår op fra kollaborationens og jodeforfolgelsernes tid.

()g sådan kunne man blive ved fra land til land. Der kræves undskyldninger 
af statsmændene for deres forgængeres synder - og der undskyldes i øst og i vest. Selv paven har været på banen!

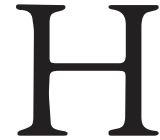
eller ikke i Danmark ser det ud til at vi nogensinde bliver færdig med verdenskrigen og besættelsen.

Den efterlod en traumatisk arv til de kommende generationer om det rigtige eller forkerte i at samarbejde med fjenden og nazismen, et traume der af både private og psykologiske og politiske grunde aldrig blev bearbejdet, men hurtigt blev kulet ned. For nationen skulle jo leve videre!

Men traumer holdes ikke sådant nede, de popper op ved enhver given lejlighed.

I 90'erne og $\mathrm{i}$ årene omkring årtusindskiftet har besættelsen været på offentlighedens dagsorden som aldrig før siden befrielsessommeren 1945.

Vi ser nu en partipresse, der i årtier understøttede myten om det officielle Danmarks indsats på modstandsfronten, $\mathrm{og}$ som nu har vendt kanonerne mod samarbejdspolitikken, der fremstilles som helt igennem lurvet og amoralsk og dens eksekutorer, politikerne, som tyskervenlige og forrædere.

Parolen lyder at vi burde have kæmpet den 9. april 1940 - og fortsat modstandskampen fra første besættelsesdag. Som om valget af modstand imod en toptunet militærmaskine som den tyske er ligeså ukompliceret som at skifte skjorte! Men efter kommunismens og fjendebilledets fald er modstandssynspunktet åbenbart blevet gratis.

Den økonomiske kollaboration forkastes over én bank - som om der i Vestog Nordeuropa var noget alternativ til at handle med tyskerne, hvis man skulle redde samfundet fra at gå i stå og befolkningen fra at sulte ihjel.

Man angriber de 100.000 arbejdere på Atlanterhavsvolden og på de andre befæstningsværker for at have hjulpet Hitler imod de allierede - som om der ikke eksisterede klassekamp og arbejdsløshed under besættelsen.

Historien om redningen af de 7000 danske jøder, som vi ellers har været så stolte over på baggrund af besættelsens almindelige elendighed - og som vi da også får løbende ros for fra udlandet, er næsten forsvundet i kritikken af flygtningepolitikken i 30'erne eller forvansket i debatten om fiskernes overpriser i oktober 43.

Man tilslutter sig ganske vist i dag uforbeholdent modstandssynspunktet, men angriber modstandsbevægelsen for udskejelserne i befrielsesdagene, for "blodrusen" under retsopgøret - og for de forkerte likvideringer - som om der ikke var eller og havde været krig!

Og så får hele besættelsesgenerationen da også en sidste bredside: den var tyskervenlig, den var materialistisk, den var opportunistisk, og den hyggede sig i smug, mens hele verden stod $\mathrm{i}$ brand - for nu at citere Aakjær om den første store krig. Det er ubehagelig tale fra det trygge observationspunkt i dagens luksus-Danmark om vore forældre eller bedsteforældre, der sloges for at få våde tørv i fyret og maksimaltøj på kroppen, og som i hvert fald i de sidste krigsår måtte gå rundt med den evige angst $\mathrm{i}$ kroppen for at familje og hus kunne blive smadret under en bombe eller en allieret invasion!

eg siger ikke dette for at skjule at der ikke findes massevis af betændte og ubekvemme spørgsmål i besættelses- 
historien, spørgsmål der naturligvis skal frem i lyset og behandles. Jeg vil heller ikke benægte at den megen offentlige turbulens har bragt nye ting frem - selv om meget også har været gamle nyheder. Men - som jeg ser det - har den offentlige debat om besættelsen kammet over. Den har mistet både proportioner og sammenhæng og indføling. Den er uden vilje til at forstå de valgsituationer som politikerne eller ganske almindelige mennesker stod $i$, og den er uden blik for gråtonerne i billedet. Den forstår ikke at folk kunne være antityske og probritiske - og det var de allerfleste - og alligevel ikke sympatisere med sabotagen. For slet ikke at tale om at blive sabotører selv. For det var et hårdt og blodigt job, forbeholdt de ganske unge og de ganske få.

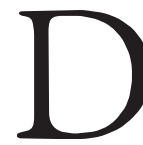
er findes en historie fra besættelsen som jeg holder meget af, og som har bevæget mig stærkt. Den er erindret af præsten Harald Sandbæk, der var sabotør i Jylland. Han fortæller om en våbenmodtagelse fra luften i forsommeren 1943, altså i modstandens barndom, at han gik fra den ene til den anden af dem som han troede ville hjælpe i sognet, men at de alle sagde nej. Så vendte han sig tvunget af nøden til en midaldrende landmand med kone og børn - og fik følgende svar: Jeg havde helst ønsket at De ikke var kommet. Men nu De er her, går jeg naturligvis med!

Det er en historie fra modstandskampens virkelighed med et perspektiv som synes ganske glemt i dag, hvor det hele er sort eller hvidt, og fordømmelsen har taget over.

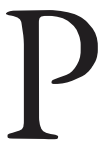

ressen har et stort ansvar for denne manglende historicering. Den nye generation af journalister har intet personligt forhold til krigen. De ved ikke nok, og de har ikke tid til at læse i bøgerne. De jagter den sensationelle og hurtige historie og går alt for ofte efter underholdningseffekten. Og de forstår ikke at den gode research tager tid.

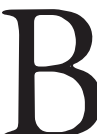

esættelsestiden bruges og misbruges som lærestykke, hvad Henning Poulsen vil sige meget om bagefter. Men vil vi tackle besættelsen som den store politiske og eksistentielle udfordring den er, og som et rustkammer for historisk erfaring til brug for os som borgere og danske i dag, så er det nødvendigt at historikerne fortsat blander sig og tager til genmæle imod tidens ahistoriske tilgang.

T eg siger endnu en gang tak for H.O. Lange-Prisen og tolker den også som opmuntring til lauget om at fortsætte Het lange og seje træk.

Note:

${ }^{1}$ Cand. mag. i historie og legemsøvelser, København 1961; dr.phil.1979. Ansat ved Udgiverselskabet for Danmarks Nyeste Historie 1961-67, ved Københavns Universitiet fra 1967. Lektor 1970. Medredaktør af Historisk Tidsskrift 198288. 


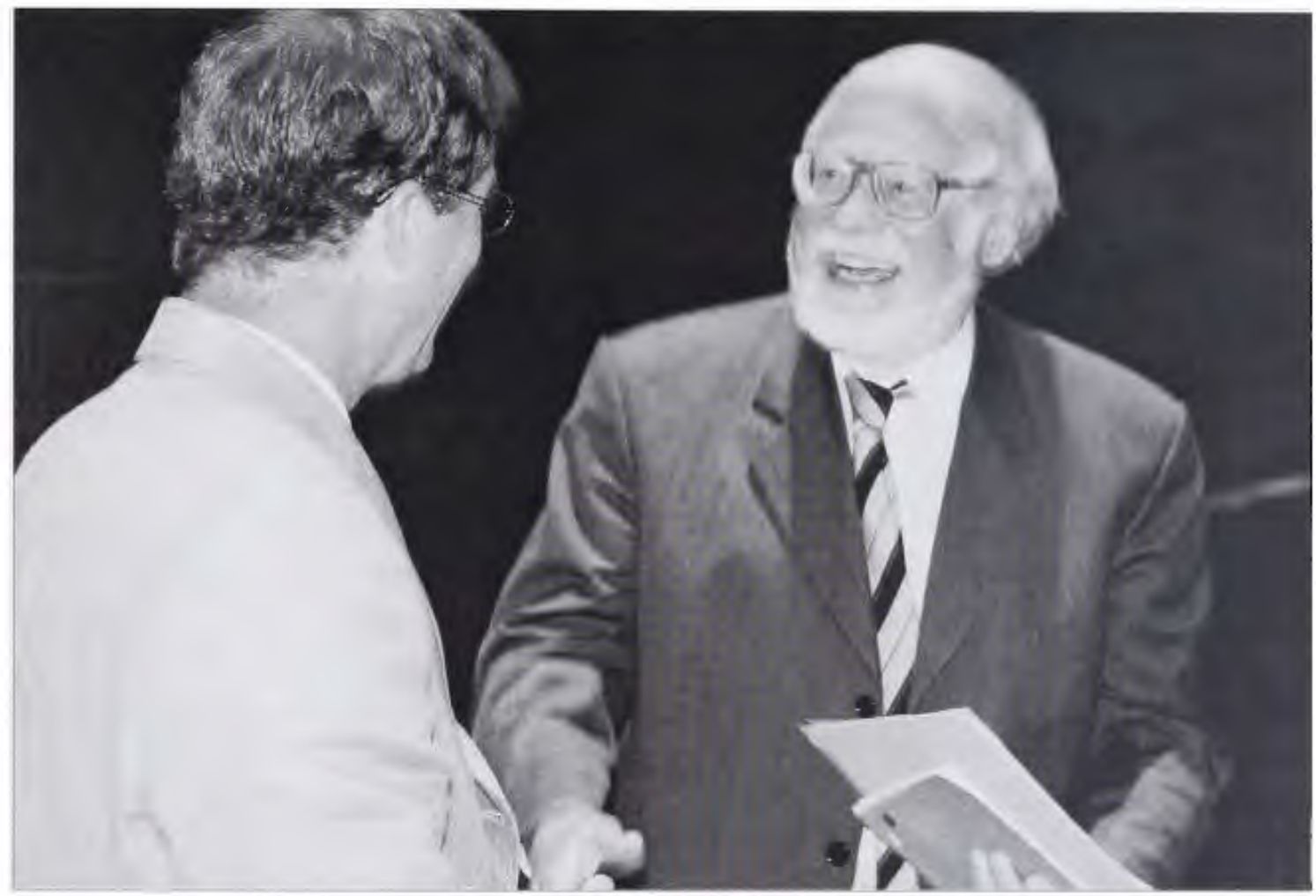

Øverst: Prisoverrakkelse ved fondsdirektør Søren Lang, G.E.C. Gad A/S. Nederst fra venstre ses lektor ved Syddansk Universitet, dr.phil. Aage Trommer, forskningschefpa Det Kongelige Bibliotek, dr.phil. John T. Lauridsen og lektor ved Københavns Universitet, dr.phil. Hans Kirchhoff, der har samlet 50 besattelsestidshistorikere om sig, og som redigerer det nye leksikon Gads leksikon om dansk besættelsestid 1940-45, der udkommer den 15. november. (Foto: Det Kgl. Bibliotek).

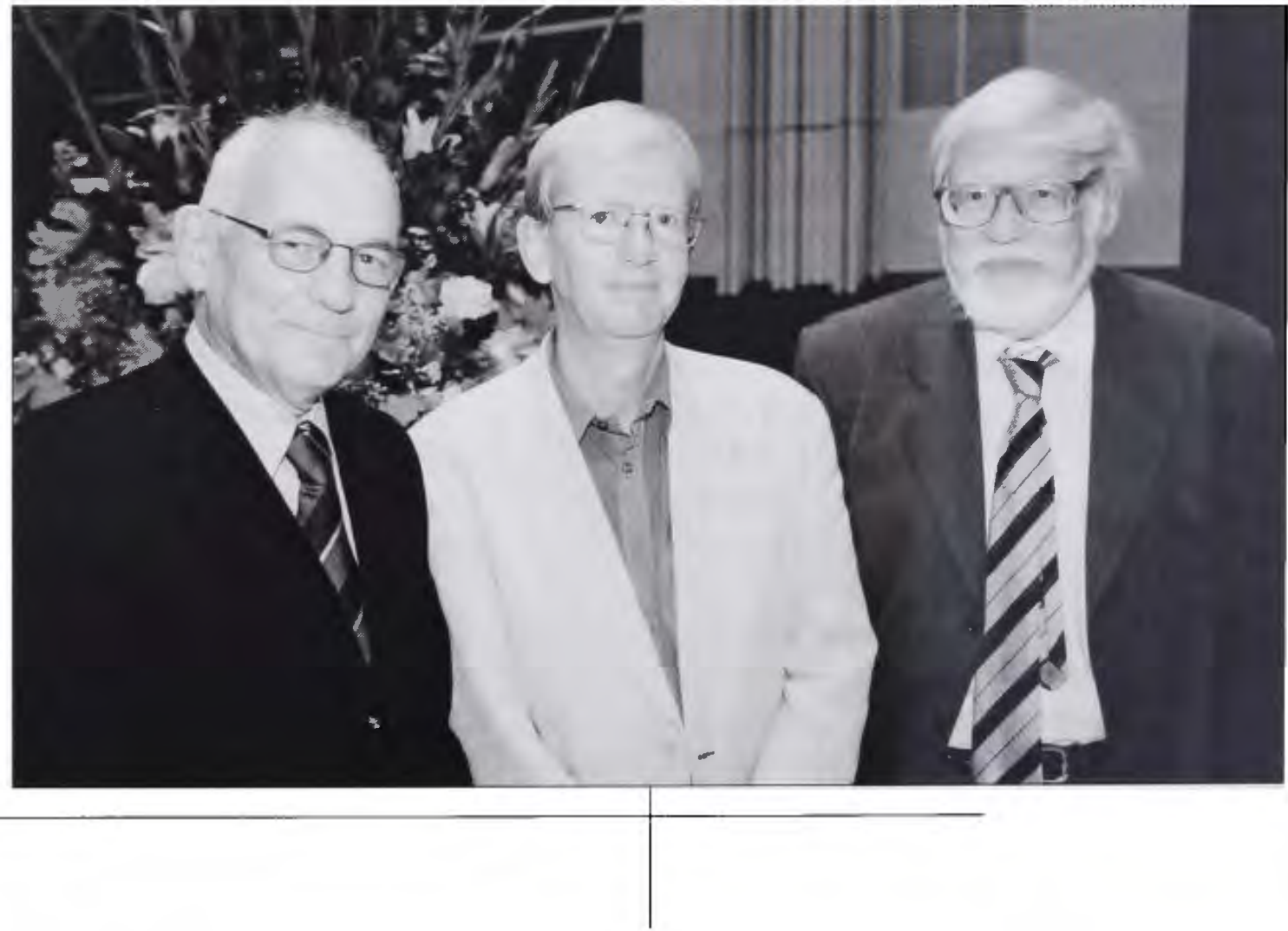

